May, 2010

\title{
Do Stronger Patent Rights Raise High-Tech Exports to the Developing World?
}

Olena Ivus 


\title{
Do stronger patent rights raise high-tech exports to the developing world?
}

\author{
Olena Ivus * \\ Department of Economics, University of Prince Edward Island, 550 University Avenue, Charlottetown PEI, Canada C1A 4P3
}

\section{A R T I C L E I N F O}

\section{Article history:}

Received 3 November 2008

Received in revised form 28 November 2009

Accepted 4 December 2009

\section{JEL classification:}

F10

K33

034

Keywords:

Trade

International law

Intellectual property rights

\begin{abstract}
A B S T R A C T
Despite over 20 years of debate, the TRIPs agreement remains very contentious. This paper evaluates the impact of strengthening patent rights (PRs) in developing countries on developed countries' exports over the 1962-2000 period. Colonial origin is used to isolate exogenous variation in PRs. The impact is then identified by examining the cross-industry difference in sensitivity to PRs. I find that the increase in PRs made in response to the TRIPs agreement added about $\$ 35$ billion (2000 US dollars) to the value of developed countries' patent-sensitive exports into 18 developing countries. This amount is equivalent to an $8.6 \%$ increase in these developing countries' annual value of patent-sensitive imports. The increase in the value of exports was driven by a quantity, rather than a price, increase.
\end{abstract}

(c) 2009 Elsevier B.V. All rights reserved.

\section{Introduction}

Despite over 20 years of debate, and almost 15 years of post agreement experience, the 1994 agreement on Trade-Related Aspects of Intellectual Property Rights (TRIPs) remains contentious. Proponents of the tougher standards embodied in the agreement argued that lax intellectual property (IP) rights in developing countries prevented innovators from earning a fair return on their inventions and reduced exports of technologically advanced products to the less developed world. Not surprisingly, opponents of the agreement disagreed, arguing that more stringent IP rights would restrict trade in the developing world's legitimate imitative products and do little more than strengthen the monopolistic power of innovators. While the TRIPs debate led to ample and still growing theoretical literature, the major and still unresolved questions are largely empirical: how has the agreement affected exports from the innovating North to the imitating South?; and in general terms, how does a strengthening of IP protection affect the flow of innovative products from North to South?

This paper attempts to isolate, and then estimate, one of the important impacts of strengthened IP protection. Specifically, it evaluates how stronger patent rights (PRs) in developing countries have affected the innovating developed world's exports into their markets. To answer this question I utilize data from both the pre- and post-TRIPs agreement period (spanning the 1960-2000 period) and examine export flows from the innovating North (24 OECD countries) to the potentially imitative South (55 developing countries). The empirical challenge is to

\footnotetext{
* Tel.: +1902566 0566 .

E-mail address: oivus@upei.ca.
}

credibly measure a causal effect from strengthened PRs to trade flows by accounting for several econometric and data problems.

My empirical strategy starts with a simple observation. Changes in the strength of PRs in developing countries are strongly correlated with their colonial origin. During the 1960-1990 period former colonies of Britain and France increased their PRs significantly more than other developing countries. For example, during this period former colonies increased their PRs by $17 \%$ while PRs protection in non-colonies fell during this period..$^{1}$ The opposite is true in the 1990-2005 period. Developing countries that were not British or French colonies increased their PRs by $50 \%$ more than colonies. The increase in stringency in this later period is clearly due to the imposition of the TRIPs agreement that required countries with lax protection to make serious adjustments to IP protection. The increase in PRs within the colonies over the earlier period may have been due to the legal and institutional legacies left by their British and French colonizers. ${ }^{2}$ The observation is that colonies differ significantly from non-colonies in the time pattern of their strengthening of PRs: the expectation is that this variation can be used to deduce something causal about PRs and trade flows.

Specifically, I perform a difference-in-difference analysis in which the growth rates of exports from the developed North to the less developed South are differenced along two dimensions: former colonies of Britain and France versus non-colonies, and patent-

\footnotetext{
${ }^{1}$ PRs protection here is measured by the Ginarte and Park (1997) index. See Section 2 for details.

${ }^{2}$ I focus on colonies that received their independence in the 20th century. This implies that the U.S., Canada, and Australia are not colonies under this definition. Since all Spanish colonies, save the Philippines, were independent by 1826 they appear here as non-colonies.
} 
sensitive industries versus patent-insensitive industries. The period is also divided into the pre- and post-TRIPs period. The growth rates of exports are examined separately for the pre-TRIPs period of 1962 1994 and the post-TRIPs period of 1994-2000.

The empirical results are striking. For both periods, I find a strengthening of PRs in developing countries raises the value of developed countries' exports in patent-sensitive industries. Perhaps not surprisingly, this effect is the strongest for industries that rely heavily on patent protection, such as medicinal and pharmaceutical products and professional and scientific equipment. The empirical results are also consistent across the two distinct periods; i.e., similar results are found when the largest increase in PRs occurs within former colonies (pre1994) and when they are within non-colonies (post-1994). The results also survive two robustness checks that relax both the definition of sensitive and insensitive industries and the definition of time periods.

Applying the further assumption that changes in PRs should have no effect on the growth rate of exports in patent-insensitive industries, I provide estimates of the dollar value of new exports created by the changes in PRs. Using this method, I find that the strengthening of PRs made in non-colonies in response to the TRIPs agreement added about $\$ 35$ billion (2000 US dollars) to the value of developed countries' patent-sensitive exports into these 18 developing countries. This amount is equivalent to an $8.6 \%$ increase in the non-colonies' annual value of patent-sensitive imports. Further, the data for the 1994-2000 period suggest that stronger PRs increased the value of exports by increasing the quantity, rather than the price, of exports.

The empirical strategy underlying these results is deceptively simple. It starts with the observation made above concerning the time pattern of PRs changes but recognizes that simply correlating trade flows with IP protection is likely to be of little value. Large exports into former colonies are likely the consequence of relationships established through colonization. Colonies could be geographically proximate, and in many cases they are connected to their colonizers through now well-worn trade routes. To address this concern, the growth rates (as opposed to levels) of export volumes are compared; that is, I examine the over time variation in both PRs and exports.

While this is surely a step in the right direction, it is unlikely that a strengthening of PRs is exogenous to other policy reforms ongoing in these countries. Over the pre-TRIPs period this seems especially significant since the change in PRs we observed in the former colonies was not required by any international agreement, and therefore could well have been part of more general market reforms intended to promote industrial development and trade. This problem can, at least partially, be addressed by examining the across industry variation in exports. For example, by grouping industries into patent-sensitive and insensitive, I examine whether the growth rate of patent-sensitive exports from the developed world responds differentially to stronger PRs in the developing world.

Finally, there is the issue of endogeneity. A large level, or fast growth rate, of trade with the developed world could very well provide an incentive for a developing country to strengthen its PRs in the hope of fostering further trade. In this sense, trade causes IP protection and not the reverse. While this is a serious concern in the 1960-1990 period, when each country chose to what extent, if any, to regulate its PRs, it is likely absent in the post-TRIPs period. During this later period, the overall push to strengthen PRs in countries with lax protection was exogenously imposed by the TRIPs agreement. While my empirical results do differ quantitatively across the two periods, the qualitative conclusions remain the same.

There is a large literature examining the TRIPs debate. Much of the theoretical literature has focused on the impact of stronger IP rights on R\&D and growth, but almost all contributions contain predictions concerning Northern exports. For example, in a static partial equilibrium world, extending IP rights from the innovating North to the non-innovating South encourages Northern firms to develop new technologies (Chin and Grossman, 1990; Deardorff, 1992), which may be more suitable to Southern tastes (Diwan and Rodrik, 1991). If Northern firms also compensate for lax IP rights by masking their technologies, which takes resources away from production, then stronger IP rights lead to increases in Northern output (Taylor, 1993). In addition, if stronger IP rights prevent imitation, then production of imitative products in the South falls and demand for Northern products rises (Maskus and Penubarti, 1997). All of these changes are expected to promote Northern exports. ${ }^{3}$ It is also true however that stronger IP rights enhance the monopolistic power of innovators (Deardorff, 1992; Chin and Grossman, 1990; Maskus and Penubarti, 1997), and if this effect is strong enough then Northern exports can fall.

The empirical literature also exhibits a wide range of results. For example, for the aggregate of manufacturing industries, researchers have found no significant impact of a strengthening in PRs (Ferrantino, 1993) to a significantly negative impact (Smith, 1999) or a significantly positive impact (Maskus and Penubarti, 1995; Rafiquzzaman, 2002). When researchers consider finer divisions than the aggregate of manufacturing, the results are often counterintuitive. Maskus and Penubarti (1995) found that exports in the least patentsensitive industries rise with a strengthening of PRs, while exports in the most patent-sensitive industries are unaffected; Co (2004) found that exports in non-R\&D-intensive industries falls, but exports in R\&D-intensive products are unaffected on average; and Fink and Primo Braga (1999) found that trade in non-fuel products expands but trade in high technology products is unchanged. Part of this variance in results surely comes from the different methods and time periods considered. As well, studies differ in the extent to which they attempt to address endogeniety and measurement error issues, and relatively few studies employ more than one cross-section of data. ${ }^{4}$

The empirical strategy employed in this paper is a combination and an extension of the approaches adopted in the literature. As such I owe much to previous work. First, I employ a country's British or French colonial origin to divide countries into groups with very different histories of PRs. This is similar to the approach of Ferrantino (1993), who showed a systematic relationship between a country's economic and geographical conditions and the strength of their IP rights; this is also akin to that of Maskus and Penubarti (1995), who employed a dummy for former British and French colonies as an instrument for their PRs. I also follow Rafiquzzaman (2002) and Co (2004) by using export data over several years to focus on growth rates and not the levels of trade; and build on contributions by Maskus and Penubarti (1995), Fink and Braga (1999), Smith (1999), Rafiquzzaman (2002), and Co (2004) by exploiting industry heterogeneity in the sensitivity to PRs to measure their effect.

The rest of the paper proceeds as follows. In Section 2, I describe the pattern of changes in PRs in colonies and non-colonies over the 1960-2005 period. In Section 3, I classify industries by their sensitivity to PRs using Cohen et al. (2000). The empirical strategy is outlined in Section 4. The results are presented in Section 5, and their economic significance is discussed in Section 6. In Section 7, I examine export price. Section 8 concludes.

\section{Colonial status and PRs}

The stringency of PRs is measured by the Ginarte and Park (1997) index. The index is available for each 5-year time period from 1960 to 2005 , and is constructed using five measures of patent laws (coverage,

\footnotetext{
3 See also the contributions by Taylor (1994), Helpman (1993), and Grossman and Lai (2004) within a growth context. In these papers exports are affected when the rate of innovation and imitation change in response to strengthened IP protection.

${ }^{4}$ The stringency of PRs in a destination country is commonly measured by Rapp and Rozek (1990) or Ginarte and Park (1997) index. Smith (1999) and Rafiquzzaman (2002) employed both indices and concluded that, because the indices were constructed using similar measures of patent laws, they produced similar results. The correlation between the Rapp and Rozek index for 1984 and the Ginarte and Park index for 1985 is 0.75 .
} 
Table 1

The means of the PRs index.

\begin{tabular}{lllllllllll}
\hline Countries & 1960 & 1965 & 1970 & 1975 & 1980 & 1985 & 1990 & 1995 & 2000 & 2005 \\
\hline $\begin{array}{l}\text { Developed } \\
\text { Developing }\end{array}$ & 2.60 & 2.77 & 2.90 & 2.91 & 3.25 & 3.30 & 3.38 & 3.75 & 3.98 & 4.02 \\
$\quad$ & & & & & & & & & & \\
$\quad$ Colonies & 2.11 & 2.21 & 2.27 & 2.29 & 2.39 & 2.47 & 2.47 & 2.58 & 3.05 & 3.61 \\
$\quad$ Non-colonies & 1.92 & 1.95 & 1.82 & 1.83 & 1.86 & 1.86 & 1.86 & 2.42 & 3.29 & 3.64 \\
\hline
\end{tabular}

membership in international patent treaties, provisions against losses of protection, enforcement mechanisms, and duration of protection). Each measure is assigned a value from 0 to 1 which equals the share of conditions a country satisfies. The final index is a sum of these five values. ${ }^{5}$ I begin with analyzing the index data for all countries. Following this, I concentrate on developing countries and examine the correlation between the changes in PRs over time in these countries and their former British or French colonial status.

The index means are reported in Table 1, where countries are classified into three groups: developed countries, developing countries formerly colonized by Britain or France (Colonies), and developing countries not colonized by Britain or France (Noncolonies). The developed countries are the OECD members. The developing countries are the countries classified by the World Bank as lower-middle or low income economies. ${ }^{6}$ The list of countries for which the index is available is presented in the Appendix. ${ }^{7}$

It is apparent that in every 5-year period under consideration developed countries had the most stringent PRs of all country groups. Until 2000, formerly colonized developing countries followed next. Further, for these two groups the index has been increasing throughout the entire period. Non-colonies, in contrast, had the least stringent PRs prior to 2000. Their index, however, increased considerably during the 1990s and as a result, Non-colonies had more stringent PRs than Colonies in 2000 and 2005.

Table 2 enumerates the changes in the index (measured in log points) over the 1960-1990 and 1990-2005 periods for Colonies and Non-colonies. It is apparent that the pattern of changes observed in the earlier period is very different from the one observed in the later period. Prior to 1990 , Colonies increased their PRs relatively more than Non-colonies. In fact, Non-colonies did not strengthen their PRs at all. After 1990, on the other hand, Non-colonies increased their PRs the most. The null hypothesis that the mean changes are equal across the two country groups is rejected at $1 \%$ level of significance for each of the two time periods. This provides evidence that Colonies and Non-colonies differ in the average behavior of changes in PRs. ${ }^{8}$

The relative progress of Colonies in strengthening PRs before the 1990s is probably a consequence of the British or French colonial relations.

\footnotetext{
${ }^{5}$ The Ginarte and Park (1997) index is preferred over the alternative index developed by Rapp and Rozek (1990), because it encompasses more countries and years.

${ }^{6}$ The classification is according to 1995 GNP per capita.

${ }^{7}$ Non-colonies which are not in the World Trade Organization (WTO) (i.e. Iran and Liberia) are excluded from the analysis. In addition, the developing countries for which the PRs index is not available before 1990 (i.e. Angola, Bulgaria, China, Ethiopia, Lithuania, Poland, Romania, Russia, Slovak Republic, Ukraine, and Vietnam) as well as the developing countries for which the export data is not available (i.e. Central African Republic, Botswana, Grenada, Malawi, Rwanda, Somalia, and Swaziland) are excluded.

8 The entire distribution of changes shows that the means are not driven by a few extreme values. For the 1960-1990 period, the median changes for Colonies and Noncolonies are 0.17 and -0.07 . For the $1990-2005$ period, they are 0.37 and 0.76 . Also, the Kolmogorov-Smirnov test reported that the null hypothesis of the equality of distributions of Colonies and Non-colonies is rejected for both periods. For the earlier period, the cumulative fraction plot of Colonies lies below that of Non-colonies $98 \%$ of the time. For the later period, the cumulative fraction plot of Non-colonies lies below that of Colonies $99 \%$ of the time. Further, the magnitudes of changes and their statistical significance are not driven by aggregation over time. The difference between the changes in the index for Colonies and Non-colonies is positive and statistically significant for 1965, 1970, and 1985; and it is negative and statistically significant for 1995 and 2000.
}

Table 2

Mean changes in the PRs index.

\begin{tabular}{lcc}
\hline Developing countries & $1960-1990$ & $1990-2005$ \\
\hline Colonies & 0.166 & 0.373 \\
Non-colonies & -0.067 & 0.765 \\
Difference & $0.233^{* * *}$ & $-0.392^{* * *}$ \\
\hline
\end{tabular}

Note: The data is in log point changes; ${ }^{* * *}$ denotes $1 \%$ significance level; Means comparison test: $H_{0}$ : difference $=0, H_{1}$ : difference $\neq 0$.

Many researchers have argued that colonizers affected the formation and successive development of their colonies' institutions of law and private property. ${ }^{9}$ This initial colonial base could then provide a fertile environment for a developing country to strengthen PRs slowly over time. Britain in France, in particular, had well developed patent systems which had a strong influence on their colonies during the 19th century (Khan, 2004). In addition, during the late 19th and early 20th centuries, when the importance of IP became well recognized among industrialized countries, British and French colonies were still dependent on their colonizers (most of them received independence only after 1945). ${ }^{10}$

In contrast to the pre-1990 period, the relative progress of Noncolonies in strengthening PRs after 1990 is a consequence of the TRIPs agreement signed in 1994. TRIPs is an international agreement that sets down minimum standards of IP rights at a level of major industrialized countries. Unlike the previous IP conventions (Paris Convention, Berne Convention, Rome Convention, and treaty on integrated circuits), the TRIPs agreement stipulates effective enforcement. ${ }^{11}$ It was designed to achieve universal standards of IP laws, which necessarily required asymmetric increases in the strength of IP rights across the world (Gaisford and Richardson, 2000). To enact the strong standards mandated by TRIPs, countries with weak PRs, such as Non-colonies, were required to strengthen their PRs relatively more, leading to the two very different episodes we see in Table $2 .{ }^{12}$

\section{Industry sensitivity to PRs}

Having described the changes in the PRs index and their correlation with colonial status of developing countries, I proceed with describing the data used for the analysis.

The export data are by 3-digit ISIC (Rev. 2) industry and available for each year from 1962 to $2000 .^{13}$ The value of exports (in nominal US dollars) into each developing country from the Appendix is aggregated over all developed countries available in the data set. ${ }^{14}$

\footnotetext{
${ }^{9}$ For instance, Barro (1996), Porta et al. (1999), and Hall and Jones (1999).

${ }^{10}$ Unlike Britain and France, Spain, for example, was less developed and had a lower per capita rate of patenting. Its patent system was constructed to profit from foreign innovation rather than stimulate domestic innovation (Khan, 2004). Spain could not have much influence on patent institutions of its colonies because all Spanish colonies, save the Philippines, became independent by 1826 . This is long before the Paris Convention for the Protection of Industrial Property, which is the first major international IP treaty, entered into force in 1884.

${ }^{11}$ For example, trade disputes over PRs can be pursued through the WTO dispute settlement system.

12 Depending on the level of development of the country concerned, WTO members were given different transitional periods to comply with the TRIPs agreement. The finding about the relative progress of Non-colonies in strengthening PRs during the post-1990 period is robust to sensitivity tests altering the country classification (excluding LDCs and countries which delayed the introduction of patent provisions to 2005; or excluding countries that became WTO members after 1990).

${ }^{13}$ I aggregate the original NBER-UN world trade data, available at 4-digit SITC level, into 2-digit levels and then, use industry concordances to obtain data by 3-digit ISIC codes (Rev. 2). The original NBER-UN world trade data comes from Feenstra et al. (2004) and is available at www.nber.org/data. The industry concordances come from Maskus (1989) and are available at http://www.macalester.edu/research/economics/ page/haveman/Trade.Resources/tradeconcordances.html.

${ }^{14}$ I aggregate exports over all developed countries to ensure that developed countries' multilateral resistance factors which vary with time do not interfere with my results. With no control for these factors, the estimates will likely suffer from omitted variables bias. This could be especially problematic when data is differenced over a long time period, such as the pre-TRIPs 1962-1994 period.
} 
Table 3

Industry classification.

\begin{tabular}{ll}
\hline Patent-sensitive industries & Patent-insensitive industries \\
\hline $\begin{array}{l}\text { Medicinal and pharmaceutical } \\
\text { products (3522) }\end{array}$ & Non-ferrous metals (372) \\
$\begin{array}{l}\text { Professional and scientific } \\
\text { equipment (385) }\end{array}$ & Non-metallic mineral products (369) \\
$\begin{array}{l}\text { Other chemicals (352) } \\
\text { Industrial chemicals (351) } \\
\text { Non-electrical machinery (382) }\end{array}$ & Electrical machinery (383) \\
\hline
\end{tabular}

Note: ISIC codes, Rev. 2 are in brackets.

The industries analyzed are classified according to their sensitivity (or lack thereof) to PRs. The classification draws on the ranking of industries by the effectiveness of patent protection documented in Cohen et al. (2000). It is presented in Table 3.

In the analysis, I evaluate the behavior of exports in patentsensitive industries relative to that in patent-insensitive industries. Consequently, it is particularly important to classify industries correctly. I only consider industries that fall into one of the two categories. Patent-sensitive category consists of industries which have the highest effectiveness of patents in protecting "competitive advantage" from patented inventions. Patent-insensitive category consists of industries which have the lowest patent effectiveness, and which are not covered by other categories of IP protection. ${ }^{15}$

Initially, I perform the analysis on the aggregate industry groups. Following this analysis, I disaggregate the industry groups and analyze the growth rates of exports in individual industries. This extra step serves two purposes. First, it is used to verify that the grouping of industries does not bias the results. Second, it allows comparing estimates across individual industries to make sure that they are sensible and quite intuitive.

\section{Empirical strategy}

In this section, I relate the strength of developing countries' PRs to developed countries' exports. The value of exports into Colonies is partially a consequence of the relationships established through colonization itself. For example, colonies could be geographically proximate, connected to their colonizers by direct trade routes, or share common tastes and customs. These factors lead to permanent differences in exports across Colonies and Non-colonies. If left unaccounted for, they would interfere with my evaluation of the impact of strengthening PRs. To effectively control for these factors, which are specific to each country group and do not vary with time, over time variation of exports can be used. Specifically, the mean growth rates, as opposed to the mean values, of exports into Colonies and Noncolonies can be compared.

Even if we focus on export growth exclusively, potential problems with the approach remain. The stringency of PRs in a country is but one of several factors that determine export growth. For example, domestic reforms designed to stimulate economic development or trade are all expected to go together with a policy of strengthening PRs. Nonetheless, as long as these reforms have an impact common to all industries within a country, they can be accounted for by using across industry variation in sensitivity to PRs. Specifically, the dif-

\footnotetext{
${ }^{15}$ It is important that patent-insensitive industries are not covered by other categories of IP protection, because the stringency of PRs in a country is correlated with the stringency of other IP rights. Park and Lippoldt (2008), for example, document a fairly high correlation of the PRs index with indices for copyrights and trademarks. Thus, I exclude from the analysis three industries which are indicated to have the lowest patent effectiveness in Cohen et al. (2000) but are covered by other IP rights. These industries are: (i) publishing, printing and reproduction of recorded media industry, which is protected by copyrights; (ii) food industry, which is protected by plant variety rights and geographical indications (Maskus, 2006); and (iii) textile industry, which is protected by trademarks (Keenan et al., 2004).
}

ference in the growth rate of exports across patent-sensitive and patent-insensitive industries can be examined for each country.

Some policy reforms, such as the global movement towards liberalized trade, affect industries differentially. Nonetheless, because these reforms are common to Colonies and Non-colonies, they are accounted for when the growth rates of exports between the two country groups are compared.

Finally, even if we focus on the comparison of the mean growth rates of exports in patent-sensitive (relative to patent-insensitive) industries in Colonies and Non-colonies, it might be that the stringency of PRs is endogenously determined by trade. For example, an initially high growth rate of high-tech exports from developed countries could have provided incentives for Colonies to strengthen their PRs in order to promote further growth. In this case, the positive association between the variables could bias the causal inference about the impact of strengthening PRs on export growth.

The endogeneity problem is a serious concern in the pre-TRIPs period, when it was an individual choice of each country to what extent, if any, to regulate its PRs. However, it is likely absent in the post-TRIPs period, when country-level regulation of IP rights was internationally mandated by the TRIPs agreement. When the Uruguay Round ended, its outcome was presented as a "single undertaking", to be accepted or rejected as a whole. Acceptance of all agreements, including TRIPs, was a compulsory requirement of WTO membership. Stegemann (2000) argues in this respect the following:

It is unlikely that any of the newly industrialized, developing or transition countries would have accepted the TRIPS Agreement if it had stood by itself, without compensating concessions based on other agreements in the WTO system. Also, many of these countries might not have accepted the TRIPS obligations in exchange for the new market access concessions obtained during the Uruguay Round, because these were meager and uncertain ... By 1994 everybody knew what the realistic alternative (to accepting the TRIPS Agreement) was: being forced into bilateral agreements to guarantee increased protection of intellectual property in exchange for continued access to US markets, without possessing the rights granted by the multilateral system and the collective security of its dispute settlement procedures (Klaus Stegemann, 2000 p. 1243).

All countries in the non-colony group are WTO members and hence, were required to comply with strong standards of PRs imposed by the TRIPs agreement. The overall push to strengthen PRs in Noncolonies during the 1990s was exogenously imposed.

Countries targeted by the TRIPs agreement were not selected randomly. These were the countries with weak IP rights, which in turn were determined by a range of historical factors, potentially affecting trade as well. By using colonial status to categorize countries into two groups, I am able to discern the pattern of changes in PRs brought about by the TRIPs agreement. Next, by comparing the mean growth rates of exports in patent-sensitive (relative to patent-insensitive) industries in Non-colonies and Colonies, I am able to account for confounding factors which potentially could bias the results.

The statistical model for the industry-level value of exports into a developing country is specified as follows:

$X_{j t}^{i}=\beta^{i} P R_{j t}+\alpha_{j}+\alpha_{j t}+\gamma^{i}+\gamma_{t}^{i}+\varphi_{t}+u_{j t}^{i}$,

where $X_{j t}^{i}$ is the aggregate value of exports into developing country $j$ in industry $i$ at time $t ; P R_{j t}$ is the stringency of PRs in country $j$ at time $t$; the coefficient $\beta^{i}$ measures the sensitivity of exports to a change in PRs, which varies across industries but is constant across importing countries; $\alpha_{j}$ denotes constant country factors, such as transportation costs, distance to exporting markets, etc; $\alpha_{j t}$ denotes country factors that vary with time, such as income levels, market environments, 
openness, price indexes, etc; $\gamma^{i}$ denotes constant industry factors, such as fixed factor requirements; $\gamma_{t}^{i}$ denotes industry factors that vary with time, such as factor productivity, technological progress, and international trade policy measures; $\varphi_{t}$ denotes a set of common time dummies; $u_{j t}^{i}$ is the stochastic error term. All variables are measured in logs.

To remove possible level effects, represented by $\alpha^{i}$ and $\gamma^{i}$, the data can be transformed into growth rates. In this case, specification (Eq. (1)) simplifies to:

$\Delta X_{j t}^{i}=\beta^{i} \Delta P R_{j t}+\delta_{j t}+\tau_{t}^{i}+\theta_{t}+\varepsilon_{j t}^{i}$,

where $\Delta X_{j t}^{i}$ denotes the log change in the aggregate value of exports and $\triangle P R_{j t}$ denotes the log change in stringency of PRs over period $t$. The rest of the variables are defined as follows: $\delta_{j t}=\Delta \alpha_{j t}, \tau_{t}^{i}=\Delta \gamma_{t}^{i}$, $\theta_{t}=\Delta \varphi_{t}$, and $\varepsilon_{j t}^{i}=\Delta u_{j t}^{i}$.

Estimation of Eqs. (1) or (2) is problematic. First, the full control of factors that vary with time and affect export growth differently across importing countries is required. The set of these factors is represented by $\delta_{j t}$ in Eq. (2) and, among others, it includes variables that are correlated with the changes in the stringency of PRs in a country (e.g. domestic reforms of market environment, political freedom, openness, etc.). Since a lot of these factors are unobservable, they are left unaccounted for, leading to a potential bias in the OLS estimator. Second, the stringency of PRs is potentially measured with significant errors which again produce a biased OLS estimator. ${ }^{16}$ The first differencing and fixed effects transformation of the data may actually exacerbate measurement error bias (Solon, 1985; Griliches and Hausman, 1986). Third, a strictly exogenous measure of PRs is required. Without exogeneity, the difficulties mentioned above are much harder to resolve. Unfortunately, there is no guarantee that the PRs index is exogenous to trade. In contrast, it is very likely that the values (changes) of PRs index are predetermined by the values (growth rates) of exports.

In this paper, specification (Eq. (2)) is estimated. The approach adopted attempts to overcome the problems mentioned above by using three dimensions of data variation. The first dimension of variation is that industries exhibit different sensitivity to PRs. This industry variation can be utilized to ensure that time-varying shocks to export growth which are common to all industries within a country, represented by $\delta_{j t}$, are not confounded with strengthening PRs. For example, if strengthening PRs coincided with other domestic policy reforms promoting overall growth of exports into the country, then industry variation in sensitivity to PRs can be used to ensure that growing rates of exports are not falsely attributed to the impact of stronger PRs.

The second dimension of variation is the variation in the changes of PRs across Colonies and Non-colonies. This country variation can be used to overcome the problem of measurement errors in the PRs index. In particular, former colonial status of a country can be used to instrument the changes in the stringency of PRs over time. ${ }^{17}$

The third dimension of variation is time variation. This variation permits analysis of the data over two distinct periods (before and after the TRIPs agreement was implemented) in order to assess whether the results for the pre-TRIPs period are contaminated by an endo-

\footnotetext{
${ }^{16}$ An important concern is that the Ginarte and Park index is based on laws on the books. To the extent that enforcement is imperfect, the index overstates the true stringency of PRs.

${ }^{17}$ It may be true that measurement errors in the values of the index are correlated with colonial status. However, this correlation is unlikely if the changes in the index over time are considered. Suppose colonies received high scores of the index based on the laws of their colonizers, but these laws were not enforced. Then the gap between the measured and actual levels of protection will be wide. Once colonization is over, however, there are few if any reasons to expect these scores to increase over time without proper enforcement mechanisms.
}

geneity problem. Furthermore, it allows analysis of the growth rate of exports over longer time periods. This is important since the growth rates of exports are unlikely to respond immediately to a change in PRs. Thus, longer time periods are required to be able to cover their full adjustment. These three variations together serve to identify the impact of strengthening PRs on export growth.

Let $\Delta X_{j T}^{i}$ be defined as the average annual log change in the aggregate value of developed countries' exports into developing country $j$ in industry $i$ over period $T$ :

$\Delta X_{j T}^{i} \equiv \begin{cases}\left(\ln X_{j, 1994}^{i}-\ln X_{j, 1962}^{i}\right) /(1994-1962) & \text { for } T=T_{1}, \\ \left(\ln X_{j, 2000}^{i}-\ln X_{j, 1994}^{i}\right) /(2000-1994) & \text { for } T=T_{2}\end{cases}$

where $T=T_{1}$ is the pre-TRIPs $1962-1994$ period; and $T=T_{2}$ is the post-TRIPs $1994-2000$ period. ${ }^{18}$ By differencing the data over long time periods, I completely remove the time series variation of the data within each period. The rationale for the use of this technique is outlined in Bertrand et al. (2001) and Griliches and Hausman (1986). ${ }^{19}$

To evaluate the impact of strengthening PRs on export growth, a simple mean comparison analysis is employed. The growth rates of exports are differenced along two dimensions: (i) patent-sensitive versus patent-insensitive industry group; and (ii) Colonies versus Non-colonies. The resultant measure compares the difference in the average behavior of the growth rates of exports in the patentsensitive relative to patent-insensitive industry group for Colonies with that of Non-colonies. Because this measure is related to the difference in the mean changes in PRs across Colonies and Noncolonies, its sign can be used to infer the direction of the impact of strengthening PRs on export growth.

Let $i=s$ stand for the patent-sensitive industry group and $i=n$ stand for patent-insensitive industry group. Then, the difference in the growth of exports across the two industry groups is given by $\Delta X_{j t}^{s / n} \equiv \Delta X_{j t}^{S}-\Delta X_{j t}^{n}$. It eliminates $\delta_{j t}$ as well as $\theta_{t}$ from Eq. (2). In long difference form, the equation for the outcome variable is now specified as:

$\Delta X_{j T}^{S / n}=\left(\beta^{s}-\beta^{n}\right) \Delta P R_{j T}+\tau_{T}^{s / n}+\varepsilon_{j T}^{s / n}$,

where $\tau_{T}^{s / n}=\tau_{T}^{s}-\tau_{T}^{n}$ and $\varepsilon_{j T}^{s / n}=\varepsilon_{j T}^{s}-\varepsilon_{j T}^{n}$. The outcome variable $\Delta X_{j T}^{s / n}$ approximates the growth rate of exports in patent-sensitive relative to patent-insensitive industry group over the long period $T$. To instrument the change in PRs, colonial status is used. The causal effect of strengthening PRs on export growth is recovered under key assumption that colonial status does not directly determine the growth rate of exports in patent-sensitive relative to patentinsensitive industry group. It only affects $\Delta X_{j T}^{S / n}$ indirectly by affecting $\Delta P R_{j T}$. That is, $E\left[\varepsilon_{j T}^{S / n} \mid j=c\right]=E\left[\varepsilon_{j T}^{S / n} \mid j=n c\right]$, where $j=c$ index Colony and $j=n c$ index Non-colony. This assumption would fail if the decision to strengthen PRs was determined partly as a function of export growth. For example, the relatively high growth rate of hightech exports into Colonies, compared to Non-colonies, could have provided incentives for Colonies to strengthen their PRs in order to further promote export growth. While this is the serious concern in the pre-TRIPs period, it is likely absent in the post-TRIPs period for reasons given earlier.

\footnotetext{
${ }^{18}$ The export data is available only from 1962 to 2000.

19 Bertrand et al. (2001) examined the problem of serial correlation in the context of the difference-in-difference estimation. In order to remove the bias in the estimated standard errors that serial correlation introduces, collapsing the time series dimension of the data by averaging over the longest periods possible was recommended Griliches and Hausman (1986) examined the problem of measurement errors in panel data. It was concluded that the long differencing estimator is often the optimal estimator which minimizes inconsistency.
} 
Under the assumption stated above, the estimate of the impact of strengthening PRs on export growth in patent-sensitive relative to patent-insensitive industries is given by:

$\widehat{\beta}^{s-\beta^{n}}=\left(\overline{\Delta X}_{T}^{S / n, c}-\overline{\Delta X}_{T}^{S / n, n c}\right) /\left({\overline{\Delta P R_{T}^{c}}}^{c}-\overline{\Delta P R}_{T}^{n c}\right) \quad$ for $T=T_{1}$,

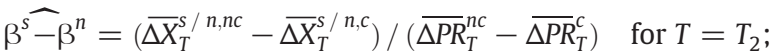

where $\overline{\Delta X}_{T}^{S / n, c}$ is the sample average of $\Delta X_{j T}^{S / n}$ over the part of the

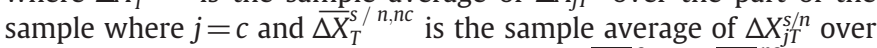
the part of the sample where $j=n c$. Similarly, $\overline{\Delta P R}_{T}^{c}$ and $\overline{\Delta P R}_{T}^{n c}$ are the sample averages of $\triangle P R_{j T}$ over the part of the sample where $j=c$ and $j=n c$ respectively.

$\beta^{s-\beta^{n}}$ is the Wald estimator. It is equivalent to an instrumental variable estimator, where the change in PRs is instrumented by binary colonial status. I use the first-stage $F$ statistic to test whether colonial status is a weak instrument. The $F$ statistic equals 16.88 in the regression $\Delta P R_{j T_{1}}=\alpha+\beta c+\varepsilon_{j T_{1}}^{s / n}$, where $c$ is the dummy that equals one if $j=c$. The $F$ statistic equals 15.23 in the regression $\Delta P R_{j T_{2}}=$ $\alpha+\beta n c+\varepsilon_{j T_{1}}^{s / n}$, where $n c$ is the dummy that equals one if $j=n c$. Following Stock et al. (2002), I conclude that colonial status is a strong instrument.

I proceed in two steps. First, I compute the difference in the mean growth rate of exports in patent-sensitive relative to patent-insensitive industry group in Colonies and Non-colonies. I use the simple difference in means test to obtain the next measure:

$D D_{T} \equiv\left\{\begin{array}{lll}\overline{\Delta X}_{T}^{S / n, c}-\overline{\Delta X}_{T}^{S / n, n c} & \text { for } & T=T_{1} \\ \overline{\Delta X}_{T}^{S / n, n c}-\overline{\Delta X}_{T}^{S / n, c} & \text { for } & T=T_{2}\end{array} ;\right.$

The $D D_{T}$, which I refer to as the difference-in-difference measure, is the simple treatment versus control measure. For the pre-TRIPs period, Colony is the treatment group; or the post-TRIPs period, Noncolony is the treatment group. ${ }^{20}$

Second, I use the sign of $D D_{T}$ to infer the direction of the trade impact of stronger PRs. It was already shown that during the preTRIPs period Colonies strengthened their PRs more than Non-colonies and during the post-TRIPs period Non-colonies strengthened their PRs

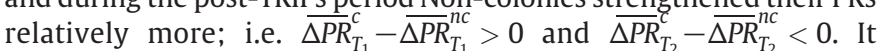
follows from Eqs. (5) and (6) that if the sign of $D D_{T}$ is positive in $T_{1}$ and $T_{2}$, strengthening PRs promotes export growth patent-sensitive relative to patent-insensitive industries. In contrast, if this sign is negative in both periods, strengthening PRs hampers export growth in patent-sensitive relative to patent-insensitive industries. Further, if this sign differs across the two periods, then the endogeneity of PRs to trade is likely to bias the estimator for the earlier period and thus, only $D D_{T}$ for the later period is reliable.

I then compute $\beta^{s-\beta^{n}}$ from Eqs. (5) and (6). Unfortunately, the PRs index is available only for 5-year time periods. The changes in PRs over the 1962-1994 and 1994-2000 periods are unavailable. Thus, to compute $\beta^{s}-\beta^{n}$, I assume that all of the changes in PRs in the 1990s were brought about by the TRIPs agreement. As such, the change in the export growth over the 1994-2000 period is related to the change in PRs over the 1990-2000 period. In the same way, the change in the export growth over the 1962-1994 period is related to the change in PRs over the 1960-1990 period.

\section{Empirical results}

Table 4 shows the results for the pre-TRIPs period. Column 1 shows the mean growth rates of exports in the patent-sensitive industry

\footnotetext{
${ }^{20}$ Alternatively, $D D_{T}$ can be obtained from dummy variable regressions: $D D_{1}=\beta_{1}$ in the regression $\Delta X_{j T}^{s / n}=\alpha+\beta_{1} c+\varepsilon_{j T}^{s / n}$ and $D D_{2}=\beta_{2}$ in the regression $\Delta X_{j T}^{s / n}=\alpha+\beta_{1} n c+\varepsilon_{j T}^{S / n}$.
}

Table 4

Average annual growth in exports over 1962-1994.

\begin{tabular}{|c|c|c|c|}
\hline \multirow[t]{2}{*}{ Countries } & \multicolumn{3}{|l|}{$\overline{\Delta X}_{T_{1}}^{i, j}$} \\
\hline & $i=s$ & $i=n$ & $i=s / n$ \\
\hline $\begin{array}{l}\text { Colonies } \\
j=c\end{array}$ & 0.0735 & 0.0650 & 0.0085 \\
\hline $\begin{array}{l}\text { Non-colonies } \\
j=n c\end{array}$ & 0.0951 & 0.1057 & -0.0106 \\
\hline $\begin{array}{l}\text { Difference } \\
\overline{\Delta X}_{T_{1}}^{i, c}-\overline{\Delta X}_{T_{1}}^{i, n c}\end{array}$ & $-0.0216^{* *}$ & $-0.0407^{* * *}$ & $0.0191^{* * *}$ \\
\hline
\end{tabular}

Note: *** and * denote $1 \%$ and $10 \%$ significance levels. The data is in log point changes. Sample size: 53 observations (34 Colonies and 19 Non-colonies).

group into Colonies (row 1), into Non-colonies (row 2), and across the two country groups (row 3 ). Column 2 shows the mean growth rates of exports in the patent-insensitive industry group. The means across the two industry groups are compared in column 3.

Inspection of rows 1 and 2 provides a comparison of the growth rates of exports in Colonies and Non-colonies. It is apparent that exports into Colonies (the treatment group for this period) increased less than exports into Non-colonies in both industry groups. In the patent-sensitive industry group, the growth rate of exports into Colonies was 0.0216 points lower, and in the patent-insensitive industry group, it was 0.0407 points lower. By itself this may suggest that strengthening PRs has a negative impact on exports. But this across-country disparity in the growth rates was smaller for the patent-sensitive industries than for the others, implying in fact that there are industry-specific effects. Across the two groups of industries, exports in patent-sensitive industries increased more for Colonies but increased less for Non-colonies. Column 3 reports that the growth rate of exports in patent-sensitive (relative to the patent-insensitive) industries was equal to 0.0085 points in Colonies and -0.0106 points in Non-colonies. As a result, the difference-in-difference measure for this period is positive and statistically different from zero. Table 4 reports that $D D_{T_{1}}=0.0191 \log$ point changes, which is about $2.63 \%$ per year. ${ }^{21}$ The null hypothesis of the equality of means is rejected at the $1 \%$ level of significance. ${ }^{22}$

To ensure that the sign of $D D_{T}$ for the pre-TRIPs period sign was not driven by the endogeneity problem, I perform the same analysis for the post-TRIPs period. The results are reported in Table 5.

Over the post-TRIPs period, exports into Non-colonies (the treatment group) fell while exports into Colonies grew in both industry groups. In patent-sensitive industries, exports grew 0.0702 points less for Non-colonies than for Colonies. In patent-insensitive industries, exports increased 0.1197 points less for Non-colonies. As before, this result suggests that strengthening PRs has a negative impact on exports, and is similarly misleading. It is evident from column 3 that exports in patent-sensitive (relative to patentinsensitive) industries increased in Non-colonies and fell in Colonies. The relative growth rates of exports were equal to 0.0030 in Noncolonies and -0.0465 in Colonies. ${ }^{23}$ The difference-in-difference measure for this period is also positive and statistically different from zero. Table 5 reports that $D D_{T_{2}}=0.0495 \log$ point changes, which is

\footnotetext{
21 To convert $D D_{T_{1}}$ from log point change into percent change the next formula should be used: $\left[\exp \left(D D_{T_{1}} \times 32\right)-1\right] / 32 \times 100$.

${ }^{22} H_{0}: D D_{T_{1}}=0, H_{1}: D D_{T_{1}} \neq 0 ; p-$ value $=0.00$. I use two-sample $t$ test with unequal variances; under the two-sample $t$ test with equal variances the results are the same.

${ }^{23}$ In response to the strengthening of PRs, firms could switch from trade to foreign direct investment or licensing in order to serve Colonies' markets. This could explain the difference in the relative growth of exports across Colonies and Non-colonies. I thank anonymous referee for this comment.
} 
Table 5

Average annual growth in exports over 1994-2000.

\begin{tabular}{|c|c|c|c|}
\hline \multirow[t]{2}{*}{ Countries } & \multicolumn{3}{|l|}{$\overline{\Delta X}_{T_{2}}^{i, j}$} \\
\hline & $i=s$ & $i=n$ & $i=s / n$ \\
\hline $\begin{array}{l}\text { Non-colonies } \\
j=n c\end{array}$ & -0.0706 & -0.0736 & 0.0030 \\
\hline $\begin{array}{l}\text { Colonies } \\
j=c\end{array}$ & -0.0004 & 0.0461 & -0.0465 \\
\hline $\begin{array}{l}\text { Difference } \\
{ }_{\Delta X_{T_{2}}^{i, n c}}^{i,}-\overline{\Delta X}_{T_{2}}^{i, c}\end{array}$ & $-0.0702^{* *}$ & $-0.1197^{* * *}$ & $0.0495^{* *}$ \\
\hline
\end{tabular}

Note: ${ }^{* * *},{ }^{* *}$, and ${ }^{*}$ denote $1 \%, 5 \%$, and $10 \%$ significance level.

Sample size: 53 observations (35 Colonies and 18 Non-colonies).

about $5.76 \%$ per year. ${ }^{24}$ The null hypothesis of the equality of means is rejected at $5 \%$ level of significance. ${ }^{25}$

Therefore, the findings suggest that the strengthening of PRs promoted developed countries' exports in patent-sensitive relative to patent-insensitive industries. The direction of the impact is consistent across the two distinct periods. It is also unaffected by the change of the treatment group.

\subsection{Sensitivity test 1: Industry variation}

In this section, I examine the sensitivity of the results to my classification of industries. I redo the mean comparison analysis by dividing up the patent-sensitive industry group. This analysis serves two purposes. First, it is used to confirm that the positive sign of $D D_{T}$ has not been unduly influenced by the grouping of industries adopted but holds at the industry-level as well. Second, it is used to explore the statistical significance of the results. The industry-level results are displayed in Table 6.

In line with the previous findings, $D D_{T_{1}}$ and $D D_{T_{2}}$ are positive. The results also show that the impact of stronger PRs on exports varies across industries. This industry variation is sensible and quite intuitive. Across the two periods, the strongest response was observed for medicinal and pharmaceutical products, for which $D D_{T_{1}}=0.0327$ and $D D_{T_{2}}=0.0756$. Professional and scientific equipment follows next, for which the respective measures are 0.0270 and 0.0676 . The weakest response in the both periods was observed for nonelectrical machinery, for which the respective measures are 0.0201 and $0.0325 .^{26}$ Most of the measures are statistically different from zero for both periods.

Several factors may be responsible for the difference in the results across the two periods. First, PRs may be endogenous to trade in the earlier period. ${ }^{27}$ In this case, the results for the later period are more reliable. Also, the IP intensity of industries may change with time. It is likely higher in the later period. ${ }^{28}$ Further, the length of the two periods is different. The later period may not be long enough for exports to adjust fully to strengthened PRs. Most importantly, the increase in PRs observed in each country group differs across the two periods. The empirical results reported in this section do not take this into account. The importance of this is explored in Section 6.

\footnotetext{
24 To convert $D D_{T_{2}}$ from log point change into percent change the next formula should be used: $\left[\exp \left(D D_{T_{2}} \times 6\right)-1\right] / 6 \times 100$.

${ }^{25} H_{0}: D D_{T_{2}}=0, H_{1}: D D_{T_{2}} \neq 0 ; p-$ value $=0.04$.

${ }^{26} \mathrm{I}$ also redo the mean comparison analysis by dividing up the patent-insensitive industry group. The results reported in Table 6 are robust to the disaggregation of the patent-insensitive industry group.

27 To examine whether the results for the pre-TRIPs period are endogenous with the British or French colonial relations, I redo the analysis by excluding Britain and France from the set of developed countries. The results, reported in the Appendix, are in line with the previous findings. All coefficients stay positive. Also, with both Britain and France excluded, the coefficients for medicinal and pharmaceutical products and professional and scientific equipment stay highly statistically significant.

28 I thank anonymous referee for this comment.
}

Table 6

Growth in exports: Industry variation.

\begin{tabular}{|c|c|c|c|c|}
\hline \multirow[t]{2}{*}{ Industries } & \multicolumn{2}{|l|}{ 1962-1994 } & \multicolumn{2}{|c|}{$1994-2000$} \\
\hline & $D D_{T_{1}}$ & St. er. & $D D_{T_{2}}$ & St. er. \\
\hline Patent-sensitive industry group & $0.0191^{* * *}$ & 0.004 & $0.0495^{* *}$ & 0.023 \\
\hline Medicinal and pharmaceutical products & $0.0327^{* * *}$ & 0.008 & $0.0756^{* *}$ & 0.034 \\
\hline Professional and scientific equipment & $0.0270^{* * *}$ & 0.005 & $0.0676^{* *}$ & 0.026 \\
\hline Other chemicals & $0.0213^{* * *}$ & 0.006 & $0.0624^{* *}$ & 0.029 \\
\hline Industrial chemicals & 0.0103 & 0.006 & $0.0726^{*}$ & 0.039 \\
\hline Non-electrical machinery & $0.0201^{* * *}$ & 0.005 & 0.0325 & 0.024 \\
\hline
\end{tabular}

Note: Growth in exports relative to the patent-insensitive industry group.

***, **, and * denote $1 \%, 5 \%$, and $10 \%$ significance level. Sample size: 53 observations.

Table 7

Growth in exports: Time variation.

\begin{tabular}{|c|c|c|c|c|c|c|}
\hline \multirow[t]{2}{*}{ Industries } & \multicolumn{2}{|c|}{$1995-2000$} & \multicolumn{2}{|c|}{ 1996-2000 } & \multicolumn{2}{|c|}{$1997-2000$} \\
\hline & $D D_{T}$ & St. er. & $D D_{T}$ & St. er. & $D D_{T}$ & St. er. \\
\hline $\begin{array}{l}\text { Patent-sensitive industry } \\
\text { group }\end{array}$ & $0.0566^{* *}$ & 0.027 & $0.0739^{* *}$ & 0.028 & $0.1082^{* * *}$ & 0.038 \\
\hline $\begin{array}{l}\text { Medicinal and } \\
\text { pharmaceutical products }\end{array}$ & $0.0678^{*}$ & 0.035 & $0.1135^{* * *}$ & 0.042 & $0.1934^{* * *}$ & 0.051 \\
\hline $\begin{array}{l}\text { Professional and } \\
\text { scientific equipment }\end{array}$ & $0.0937^{* * *}$ & 0.030 & $0.0872^{* *}$ & 0.039 & $0.1362^{* * *}$ & 0.045 \\
\hline Other chemicals & 0.0502 & 0.031 & $0.1099^{* * *}$ & 0.034 & $0.1684^{* * *}$ & 0.044 \\
\hline Industrial chemicals & $0.0834^{*}$ & 0.048 & $0.1526^{* * *}$ & 0.052 & $0.2179^{* * *}$ & 0.071 \\
\hline Non-electrical machinery & $0.0523^{*}$ & 0.027 & 0.0448 & 0.036 & $0.0675^{*}$ & 0.040 \\
\hline
\end{tabular}

Note: Growth in exports relative to the patent-insensitive industry group.

***, **, and * denote $1 \%, 5 \%$, and 10\% significance level. Sample size: 53 observations.

\subsection{Sensitivity test 2: Time periods aggregation bias}

To verify whether the results for the post-TRIPs period are sensitive to my choice of time intervals, I redo the analysis over three new intervals. I redefine the post-TRIPs period to be 1995-2000, 1996-2000, or 1997-2000. The results, displayed in Table 7, largely confirm the previous findings. Strengthening PRs has a positive impact on exports.

Moreover, the results indicate that the magnitudes of $D D_{T}$ measures and their statistical significance increase as the growth rates of exports are differenced over the shorter periods of time. For patent-sensitive industry group, for example, $D D_{T}$ increases from 0.0566 for the 19952000 period to 0.0739 for the $1996-2000$ period and then, to 0.1082 for the 1997-2000 period. Its significance level, in turn, increases to $1 \%$. This finding may be due to three reasons. First, it may be due to a lag between the time when a change in PRs occurs and the time when its trade impact is manifested. Second, it may be due to transitional periods which are given to developing countries to comply with the TRIPs agreement. It may also be due to the problem of a positive autocorrelation in the error term, in which case the differencing of the data over the longest periods possible is recommended (Bertrand et al., 2001). ${ }^{29}$

\section{Economic significance}

I now compute the elasticity of the value of exports in patentsensitive (relative to patent-insensitive) industries, $\beta^{s}-\beta^{n}$, from Eqs. (5) and (6). The results are reported in Table 8.

From 1960 to 1990, the average annual rate of increase in PRs in Colonies was 0.0085 points higher than that in Non-colonies. As a result of this difference, exports in patent-sensitive (relative to patent-insensitive) industries into Colonies were growing more than these exports into Non-colonies over the 1962-1994 period. $D D_{T_{1}}=0.0191$ in Section 5 and hence, $\beta^{s-\beta^{n}}=2.25$ from Eq. (5). For each $1 \%$ increase in the PRs index the value of developed countries'

\footnotetext{
${ }^{29}$ Positive autocorrelation in the error term (if combined with autocorrelation in the independent variable) causes under-statement of standard errors. As a result, the null hypothesis of no effect is rejected more often (Bertrand et al., 2001).
} 
Table 8

The trade impact of strengthening PRs, $\beta^{s-} \beta^{n}$.

\begin{tabular}{lll}
\hline Industries & Pre-TRIPs & Post-TRIPs \\
\hline Patent-sensitive industry group & 2.25 & 1.03 \\
Medicinal and pharmaceutical products & 3.85 & 1.57 \\
Professional and scientific equipment & 3.18 & 1.40 \\
Other chemicals & 2.51 & 1.29 \\
Industrial chemicals & 1.21 & 1.51 \\
Non-electrical machinery & 2.36 & 0.67 \\
\hline
\end{tabular}

Note: Sample size: 53 observations.

exports in patent-sensitive (relative to patent-insensitive) industries increased by $2.25 \%$ during the pre-TRIPs period. From 1990 to 2000 , the average annual rate of increase in PRs in Non-colonies was 0.0482 points higher than that in Colonies. As a result, $D D_{T_{2}}=0.0495$. This implies that for each $1 \%$ increase in the PRs index the value of developed countries' exports in patent-sensitive (relative to patentinsensitive) industries increased by $1.03 \%$ during the post-TRIPs period, i.e. $\widehat{\beta^{s}-\beta^{n}}=1.03$.

For most of the industries, $\beta^{s-\beta^{n}}$ is higher in the earlier period. It is likely that the impact is underestimated for the later period, because the time interval is short. Nonetheless, the elasticities computed for the earlier and later periods provide reasonable upper and lower bounds, respectively, for the true measure of the impact of PRs. ${ }^{30}$

Applying the further assumption that PRs do not affect export growth in patent-insensitive industries, i.e. $\beta^{n}=0$, I provide estimates of the dollar value of new exports created by changes in PRs during the post-TRIPs period. ${ }^{31}$ With the total value of patent-sensitive exports into Non-colonies of about $\$ 40$ billion in 1994, 1.03\% translates into over $\$ 40$ million (2000 US dollars). Non-colonies increased their PRs by over $84 \%$ during the 1990s. This added about $\$ 35$ billion (2000 US dollars) to the value of developed countries' patent-sensitive exports into these 18 developing countries. This amount is equivalent to an $8.6 \%$ increase in the Non-colonies' annual value of patent-sensitive imports. Given that over $60 \%$ of all patent-sensitive exports into developing countries were directed into Non-colonies in 1994, it is clear why developed countries pushed for strengthening PRs in these regions.

\section{Quantity vs. Price}

The TRIPs agreement was largely opposed on the grounds that strengthening PRs increases the price of high-tech products and hence, limits developing countries' access to new technologies. The potential effect of TRIPs on product prices has been specifically recognized as the most troubling effects of granting, strengthening, or extending IP protection. The analysis employed in this paper has shown that the value of developed countries' exports in patentsensitive industries increased in response to the strengthening of PRs in developing countries. It is unclear, however, whether the increase in the value of exports was driven by a quantity or a price increase. In this section, I examine how the price of patent-sensitive exports into developing countries has been affected.

It is important to note that, by differencing the export data along country and industry dimensions, we can be sure that the increase in the export value was not driven by a relative increase in the overall price index in treated countries, or a relative increase in the price of patent-sensitive products. ${ }^{32}$ It is possible, however, that the value of patent-sensitive

\footnotetext{
30 The results reported in Table 8 also suggest that the trade impact of strengthening PRs is non-linear; it is increasing at a decreasing rate with time.

31 The assumption of $\beta^{n}=0$ may be too strong and thus, the dollar value estimates provide only a rough measure of the impact of strengthening PRs.

${ }^{32}$ First, an increase in country's overall price index does not contribute to the difference in the value of exports across patent-sensitive and patent-insensitive industries. Second, a relative increase in the price of patent-sensitive products does not contribute to the difference in the value of exports across Colonies and Noncolonies.
}

Table 9

The index of price changes, 1994-2000.

\begin{tabular}{lccccc}
\hline & Obs. & Non-colonies & Colonies & Difference & St. er. \\
\hline $\begin{array}{l}\text { Patent-sensitive industries } \\
\begin{array}{l}\text { Medicinal and pharmaceutical } \\
\text { products }\end{array}\end{array}$ & 53 & -0.298 & -0.311 & 0.013 & 0.15 \\
$\begin{array}{l}\text { Professional and scientific } \\
\quad \text { equipment }\end{array}$ & 50 & -0.075 & -0.049 & -0.026 & 0.18 \\
$\begin{array}{l}\text { Other chemicals } \\
\text { Industrial chemicals }\end{array}$ & 50 & 0.075 & -0.233 & $0.308^{* * *}$ & 0.11 \\
Non-electrical machinery & 59 & 0.159 & -0.078 & $0.237^{* *}$ & 0.11 \\
& 53 & -0.202 & -0.219 & 0.017 & 0.09 \\
$\begin{array}{l}\text { Patent-insensitive industries } \\
\text { Non-ferrous metals }\end{array}$ & 44 & 0.089 & -0.047 & 0.136 & 0.20 \\
$\begin{array}{l}\text { Non-metallic mineral products } \\
\text { Electrical machinery }\end{array}$ & 51 & -0.218 & -0.105 & -0.113 & 0.16 \\
\hline
\end{tabular}

Note: ${ }^{* * *},{ }^{* *}$, and ${ }^{*}$ denote $1 \%, 5 \%$, and $10 \%$ significance level.

exports into the treated countries has risen because of an increase in prices which is specific to patent-sensitive industries in these countries.

As before, the NBER-UN world trade data is employed. I keep the data disaggregated and organized by the 4-digit SITC codes. Price (or unit value) is computed for each developing country from the data on value and quantity of developed countries' aggregate exports. Prices are measured in nominal US dollars. Unfortunately, the data on quantity are not complete, and hence I examine prices for the post-TRIPs period only.

The change in price is computed for each 4-digit commodity as the difference in the log of price over the 1994-2000 period. I classify 4digit commodities into corresponding industries. Industrial chemicals, for example, is composed of 43 commodities, which are the varieties of dyeing, tanning and coloring materials, organic chemicals, inorganic chemicals, and fertilizers. For each industry, such as industrial chemicals, I compute an index of price changes over the 1994-2000 period. It is a weighted sum of changes in export prices across 4-digit commodities within a given industry, calculated as follows:

$$
\begin{aligned}
\Delta P_{j t}^{i} & =\sum_{k \in i} w_{j t}^{k} \Delta p_{j t}^{k}, \quad \text { where } w_{j t}^{k}=\frac{p_{j t}^{k} q_{j t}^{k}}{\sum_{k \in i} p_{j t}^{k} q_{j t}^{k}} ; \\
\Delta p_{j t}^{k} & =\log \left(p_{j t, 2000}^{k}\right)-\log \left(p_{j t, 1994}^{k}\right) ;
\end{aligned}
$$

and $\Delta p_{j}^{k}$ is the change in the price of a commodity $k$ exported to a country $j$ over the $1994-2000$ period and $q_{j}^{k}$ is the quantity of exports. The weight $w_{j}^{k}$ is the share of a commodity $k$ in the total value of exports in an industry $i$ in the initial year, i.e. 1994.

The changes in the industry-specific export price indices are summarized in Table 9. Column 2 shows the mean value of the index for Non-colonies, i.e. $\sum_{j \in n c} \Delta P_{j}^{i} / N$, where $N$ is the number of Non-colonies. Similarly, column 3 shows the mean value of the index for Colonies. ${ }^{33}$ The difference in means across the two country groups is displayed in column 4. It is apparent that the index of export price changes differs across the two groups of countries. This difference depends on industry. For professional and scientific equipment and non-metallic mineral products, the change in the price index is on average lower for Non-colonies than for Colonies. For the other industries, the index is on average higher for Non-colonies than for Colonies. The difference in means is significantly different from zero for chemicals and electrical machinery.

To ensure that the results in Table 9 are not influenced by price changes specific to Non-colonies (as opposed to Colonies), I now compare the changes in prices across industries with different sensitivity to PRs. This comparison is performed by measuring the index of price changes for each patent-sensitive industry relative to the index of price changes in the group of patent-insensitive industries. The following formula is used $\Delta P_{j}^{i} / \Delta P_{j}^{n}=\sum_{k \in i} w_{j}^{k} \Delta p_{j}^{k} / \Delta P_{j}^{n}$,

\footnotetext{
33 The negative sign of the index implies prices have on average fallen over the 19942000 period. This is a result of the appreciation in the US dollar over this period. The changes in exchange rates do not differ systematically between Colonies and Noncolonies.
} 
where $\Delta P_{j}^{n}$ is the patent-insensitive index of price changes constructed for each developing country as follows:

$\Delta P_{j}^{n}=\sum_{k \in n} w_{j}^{k} \Delta p_{j}^{k}, \quad$ where $\quad w_{j}^{k}=p_{j}^{k} q_{j}^{k} / \sum_{k \in n} p_{j}^{k} q_{j}^{k}$

that is, $\Delta P_{j}^{n}$ is a weighted sum of changes in export prices across fourdigit commodities in the patent-insensitive industry group. The weights are given by commodities' shares in the total value of exports in patent-insensitive industries in 1994.

The difference in the relative price changes across Non-colonies and Colonies is shown in Table 10. For all patent-sensitive industries, except for other chemicals, the difference in means is negative. For all patent-sensitive industries, the difference is not significantly different from zero. As such, the data suggest that the relative changes in the price of patent-sensitive products do not differ significantly across the two country groups during the 1994-2000 period.

The data show that the price of products in patent-sensitive industries (relative to that in patent-insensitive industries) did not increase in Noncolonies relative to Colonies in response to strengthening PRs. This suggests that the earlier finding that stronger IPRs increase the value of exports into developing countries was driven by a quantity, rather than a price, increase. The difference in the relative price changes does not contribute to the difference in export values across Non-colonies and Colonies, provided the decision to strengthen PRs in Non-colonies did not coincide with reforms of the competitive environment which are specific to Non-colonies and patent-sensitive industries.

\section{Conclusion}

This paper is a contribution to a long standing and still active debate over trade-related aspects of IP rights. For over 20 years economists have been debating the likely consequences of strengthening IP protection in the developing world. While the large and still growing theoretical literature has been useful in identifying a series of links between stronger IP protection and trade flows, there are few general results. This is not surprising since the relevant theory requires models of imperfect competition and at least temporary monopolistic power arising from IP rights. Theory is further complicated by investments in R\&D, a consideration of long run growth, and the possibility of active efforts at imitation.

The existing empirical evidence linking PRs and trade is also fragmentary. The results range from a finding of no impact of PRs on trade flows to both significant negative and positive effects. While some variance in results is expected from studies that consider different time periods, employ different methods, and consider different industry aggregates, this literature has also struggled with the econometric issues of endogeneity, measurement error and unobserved heterogeneity across both countries and industries. This paper combines and extends the methods employed in the existing empirical literature in an attempt to address these issues. It examines only one important aspect of the TRIPs debate-the link between PRs and exports into the developing world-by employing a difference-indifference estimation that links stronger PRs in developing countries to the differential growth in high-tech exports from the developed world.

The results are striking. For both the 1960-1994 and 1994-2000 periods, the results show a strengthening of PRs in developing countries

Table 10

The relative index of price changes, 1994-2000.

\begin{tabular}{llll}
\hline Patent-sensitive industries & Obs. & Difference & St. er. \\
\hline Medicinal and pharmaceutical products & 53 & -0.274 & 0.20 \\
Professional and scientific equipment & 50 & -0.281 & 0.17 \\
Other chemicals & 53 & 0.021 & 0.17 \\
Industrial chemicals & 50 & -0.113 & 0.17 \\
Non-electrical machinery & 53 & -0.270 & 0.23 \\
\hline
\end{tabular}

Note: The index of price changes relative to the patent-insensitive price index. raised the value of developed countries' exports in patent-sensitive (relative to patent-insensitive) industries. This effect is the strongest for industries that rely heavily on patent protection, such as medicinal and pharmaceutical products and professional and scientific equipment. The results are consistent across the two distinct periods, and robust to two sensitivity tests altering the industry group and time period definitions. Further, the data for the 1994-2000 period suggest that stronger PRs increased the value of exports into developing countries by increasing the quantity, rather than the price, of exports. This seems to indicate that strengthening PRs does not limit developing countries' access to innovative products and technologies by leading to higher prices. Using my empirical results and assuming that a change in PRs should have no effect on exports in patent-insensitive industries, I calculate that the strengthening of PRs made in non-colonies in response to the TRIPs agreement added about $8.6 \%$ to the annual value of developed countries' patent-sensitive exports into these countries. Therefore, these empirical results support the view that PRs are indeed trade relevant. Changes in PRs have real, measurable and economically significant effects on trade flows.

\section{Acknowledgments}

I would like to thank M. Scott Taylor, Chris Auld, Michael Ferrantino, James D. Gaisford, Aidan M. Hollis, Walter Park, Mohammed Rafiquzzaman, two anonymous referees, and seminar participants at the University of Calgary, Queen's School of Business, Queen's University, St. Francis Xavier University, University of Prince Edward Island, University of Saskatchewan, and Wilfrid Laurier University for helpful comments.

\section{Appendix A}

Table A1

Country groups.

\begin{tabular}{|c|c|c|}
\hline $\begin{array}{l}\text { Developed } \\
\text { countries }\end{array}$ & $\begin{array}{l}\text { Countries formerly colonized } \\
\text { by Britain or France }\end{array}$ & $\begin{array}{l}\text { Countries not colonized } \\
\text { by Britain or France }\end{array}$ \\
\hline Australia & Algeria (1962) & Bolivia \\
\hline Austria & Bangladesh (1947) & Burundi \\
\hline Belgium & Benin (1960) & Colombia \\
\hline Canada & Burkina Faso (1960) & Congo Dem. Republic (Zaire) \\
\hline Denmark & Cameroon (1960) & Costa Rica \\
\hline Finland & Chad (1960) & Ecuador \\
\hline France & Congo Republic (1960) & El Salvador \\
\hline Germany & Dominican Republic (1844) & Guatemala \\
\hline Greece & Egypt (1922) & Honduras \\
\hline Iceland & Fiji (1970) & Indonesia \\
\hline Ireland & Ghana (1957) & Nepal \\
\hline Italy & Guyana (1966) & Nicaragua \\
\hline Japan & Haiti (1804) & Panama \\
\hline Luxemburg & India (1947) & Papua New Guinea \\
\hline Netherlands & Iraq (1932) & Paraguay \\
\hline New Zealand & Ivory Coast (1960) & Peru \\
\hline Norway & Jamaica (1962) & Philippines \\
\hline Portugal & Jordan (1946) & Thailand \\
\hline Spain & Kenya (1963) & Venezuela \\
\hline Sweden & Madagascar (1960) & \\
\hline Switzerland & Mali (1960) & \\
\hline Turkey & Mauritania (1960) & \\
\hline UK & Morocco (1956) & \\
\hline \multirow[t]{13}{*}{ USA } & Niger (1960) & \\
\hline & Nigeria (1960) & \\
\hline & Senegal (1960) & \\
\hline & Sierra Leone (1961) & \\
\hline & Sri Lanka (1948) & \\
\hline & Sudan (1956) & \\
\hline & Syria (1946) & \\
\hline & Tanzania (1964) & \\
\hline & Togo (1965) & \\
\hline & Tunisia (1956) & \\
\hline & Uganda (1962) & \\
\hline & Zambia (1964) & \\
\hline & Zimbabwe (1980) & \\
\hline
\end{tabular}

Note: In brackets is the year of independence from Britain or France. Data for colonization origin is available at: https://www.cia.gov/library/publications/the-world-factbook/index.html. 
Table A2

Sensitivity to Britain and France. Pre-TRIPs period.

\begin{tabular}{|c|c|c|c|c|c|c|c|c|}
\hline Britain & Included & & Excluded & & Included & & Excluded & \\
\hline \multirow[t]{2}{*}{ France } & \multicolumn{2}{|l|}{ Included } & \multicolumn{2}{|l|}{ Excluded } & \multicolumn{2}{|l|}{ Excluded } & \multicolumn{2}{|l|}{ Included } \\
\hline & $D D_{T_{1}}$ & St.er. & $D D_{T_{1}}$ & St.er. & $D D_{T_{1}}$ & St.er. & $D D_{T_{1}}$ & St.er. \\
\hline Patent-sensitive group & $0.0191^{* * *}$ & 0.004 & 0.0087 & 0.005 & $0.0107^{*}$ & 0.006 & $0.0171^{* * *}$ & 0.005 \\
\hline Med. \& pharmaceuticals & $0.0327^{* * *}$ & 0.008 & 0.0098 & 0.008 & $0.0186^{* *}$ & 0.009 & $0.0248^{* * *}$ & 0.008 \\
\hline Prof. \& scient. equipment & $0.0270^{* * *}$ & 0.005 & $0.0184^{* * *}$ & 0.006 & $0.0221^{* * *}$ & 0.006 & $0.0249 * * *$ & 0.005 \\
\hline Other chemicals & $0.0213^{* * *}$ & 0.006 & $0.0390^{* * *}$ & 0.009 & $0.0281^{* * *}$ & 0.007 & $0.0281^{* * *}$ & 0.008 \\
\hline Industrial chemicals & 0.0103 & 0.006 & 0.0116 & 0.008 & $0.0144^{*}$ & 0.008 & 0.0071 & 0.006 \\
\hline Non-electrical machinery & $0.0201^{* * *}$ & 0.005 & 0.0062 & 0.007 & 0.0076 & 0.006 & $0.0187^{* * *}$ & 0.005 \\
\hline
\end{tabular}

Note: Growth in exports relative to the patent-insensitive industry group.

${ }^{* * *},{ }^{* *}$, and ${ }^{*}$ denote $1 \%, 5 \%$, and $10 \%$ significance level. Sample size: 53 observations.

\section{References}

Barro, R.J., 1996. Democracy and growth. Journal of Economic Growth 1, 1-27.

Bertrand, M., Duflo, E., Mullainathan, S., 2001. How Much Should We Trust Differencesin-Differences Estimates? Working Paper No. 01-34, MIT Department of Economics.

Chin, J.C., Grossman, G.M., 1990. Intellectual property rights and North-South trade. In: Jones, Ronald W., Krueger, Anne O. (Eds.), The Political Economy of International Trade: Essays in Honor of Robert E. Baldwin. Basil Blackwell, Oxford, pp. 90-107.

Co, C.Y., 2004. Do patent rights regimes matter? Review of International Economics 12 , 359-373.

Cohen, W.M., Nelson, R.R., Walsh, J.P., 2000. Protecting their Intellectual Assets: Appropriability Conditions and Why U.S. Manufacturing Firms Patent (or Not). NBER Working Paper no.7552.

Deardorff, A.V., February 1992. Welfare effects of global patent protection. Economica 59 (233), 35-51.

Diwan, I., Rodrik, D., 1991. Patents, appropriate technology, and north-south trade Journal of International Economics 30 (1-2), 27-47.

Feenstra, R.C., Lipsey, R.E., Deng, H., Ma, A.C., Mo, H., 2004. World Trade Flows: 1962 2000. NBER Working Paper no.11040.

Ferrantino, M., 1993. The effect of intellectual property rights on international trade and investment. Weltwirtschaftliches Archiv 129, 300-333.

Fink, C. Primo Braga, C.A., 1999. How Stronger Protection of Intellectual Property Rights Affects International Trade Flows. Policy Research Working Paper Series No. 2051. The World Bank.

Gaisford, J.D., Richardson, R.S., 2000. The TRIPS disagreement: should GATT traditions have been abandoned? Estey Centre Journal of International Law and Trade Policy 1, 137-169.

Ginarte, J.C., Park, W.G., 1997. Determinants of patent rights: a cross-national study. Research Policy 26, 283-301.

Griliches, Z., Hausman, J.A., 1986. Errors in variables in panel data. Journal of Econometrics 31 (1), 93-118.

Grossman, G.M., Lai, E.L.-C., 2004. International protection of intellectual property. The American Economic Review 94 (5), 1635-1653.

Hall, R.E., Jones, C.I., 1999. Why do some countries produce so much more output per worker than others? Quarterly Journal of Economics 114, 83-116.

Helpman, E., 1993. Innovation, imitation, and intellectual property rights. Econometrica $61(6), 1247-1280$
Keenan, M., Saritas, O., Kroener, I., 2004. A dying industry-or not? The future of the European textiles and clothing industry. Foresight 6 (5), 313-322.

Khan, B.Z., 2004. The Democratization of Invention: Patents and Copyrights in American Economic Development, 1790-1920. Cambridge University Press, New York

Maskus, K.E., 1989. Comparing international trade data and product and national characteristics data for the analysis of trade models. In: Hooper, P., Richardson, J.D. (Eds.), International Economics Transactions: Issues in Measurement and Empirical Research. University of Chicago Press, Chicago, IL, pp. 17-56.

Maskus, K.E., 2006. Intellectual property rights in agriculture and the interests of AsianPacific,. economies. The World Economy 29 (6), 715-742.

Maskus, K.E., Penubarti, M., 1995. How trade related are intellectual property rights? Journal of International Economics 39, 227-248.

Maskus, K.E., Penubarti, M., 1997. Patents and international trade: an empirical study. In: Maskus, K.E., et al. (Ed.), Quiet Pioneering: Robert M. Stern and His International Economic Legacy. University of Michigan Press, Ann Arbor, MI, pp. 95-118.

Park, W.G., Lippoldt, D., 2008. Transfer and the Economic Implications of the Strengthening of Intellectual Property Rights in Developing Countries. OECD Trade Policy Working Papers (62).

Porta, R.La, Lopez de Silanes, F., Shleifer, A., Vishny, R., 1999. The quality of government. Journal of Law, Economics and Organization 15, 222-279.

Rafiquzzaman, M., 2002. Impact of patent rights on international trade: evidence from Canada. Canadian Journal of Economics 35, 307-330.

Rapp, R.T., Rozek, R.P., 1990. Benefits and Costs of Intellectual Property Protection in Developing Countries. Working Paper No. 3. National Economic Research Associates, Inc, Washington, D.C.

Smith, P.J., 1999. Are weak patent rights a barrier to U.S. exports? Journal of International Economics 48, 151-177.

Solon, G., 1985. Comment on Benefits and limitations of panel data by C. Hsiao. Econometric Review 4, 18385.

Stegemann, K., 2000. The integration of intellectual property rights into the WTO system. The World Economy 23 (9), 1237-1267 09.

Stock, J.H., Wright, J.H., Yogo, M., 2002. A survey of weak instruments and weak identification in generalized method of moments. Journal of Business \& Economic Statistics 20 (4), 518-529 October.

Taylor, M.S., 1993. TRIPS, trade, and technology transfer. Canadian Journal of Economics 26, 625-638.

Taylor, M.S., 1994. TRIPS, trade, and growth. International Economic Review 35, 361-382. 